\begin{abstract}
Iranica
Abstracta Iranica Revue bibliographique pour le domaine irano-aryen

Volume 34-35-36 | 2017

Comptes rendus des publications de 2011-2013
\end{abstract}

\title{
Michael Shenkar. Aniconism in the Religious Art of Pre-Islamic Iran and Central Asia
}

Julien Cuny

\section{(2) OpenEdition}

Édition électronique

URL : http://journals.openedition.org/abstractairanica/42309

DOI : 10.4000/abstractairanica.42309

ISSN : 1961-960X

Éditeur :

CNRS (UMR 7528 Mondes iraniens et indiens), Éditions de l'IFRI

Référence électronique

Julien Cuny, "Michael Shenkar. Aniconism in the Religious Art of Pre-Islamic Iran and Central Asia », Abstracta Iranica [En ligne], Volume 34-35-36 | 2017, document 35, mis en ligne le 30 juillet 2017, consulté le 26 septembre 2020. URL : http://journals.openedition.org/abstractairanica/42309; DOI : https://doi.org/10.4000/abstractairanica.42309

Ce document a été généré automatiquement le 26 septembre 2020.

Tous droits réservés 


\title{
Michael Shenkar. Aniconism in the Religious Art of Pre-Islamic Iran and Central Asia
}

\author{
Julien Cuny
}

\section{RÉFÉRENCE}

Michael Shenkar. « Aniconism in the Religious Art of Pre-Islamic Iran and Central Asia ». Bulletin of the Asia Institute, 22, 2008 [2012], p. 239-256.

1 L'article, très documenté, traite autant de l'aniconisme, que des représentations divines sous forme animalière, et enfin de l'émergence des représentations divines anthropomorphiques dans le monde iranien. L'aniconisme en serait une tendance originelle à chercher dans le domaine steppique, renforcé par des conceptions venues de Mésopotamie. La typologie établie par l'A. montre le foisonnement des pratiques : « aniconisme matériel " ou symbolisme aniconique, essentiellement attesté dans le monde steppique ; manifestation de la présence divine par un char laissé vide (« emptyspace aniconism »); " aniconisme élémentaire » caractérisé par les représentations d'autels du feu ; « semi-aniconisme » du disque ailé d'où émerge un buste masculin. L'A. rappelle que les représentations divines sous forme animalière sont rarement explicites. Les représentations sous forme humaine sont bien attestées à compter de l'époque kouchane puis sous les Sassanides, mais elles connaissent des antécédents dès l'époque achéménide, elles ne seraient donc pas à mettre au compte uniquement d'une influence gréco-romaine. 


\section{AUTEURS}

\section{JULIEN CUNY}

Musée du Louvre 